http://doi.org/10.35784/iapgos.917

\title{
ENVIRONMENT OF ELECTROMAGNETIC COMPATIBILITY OF RADIO-ELECTRONIC COMMUNICATION MEANS
}

\author{
Heorhii Rozorinov ${ }^{1}$, Oleksandr Hres ${ }^{2}$, Volodymyr Rusyn ${ }^{2}$, Petro Shpatar ${ }^{2}$ \\ ${ }^{1}$ National Technical University of Ukraine "Igor Sikorsky Kyiv Politechnic Institute", Kyiv, Ukraine, ${ }^{2}$ Yuriy Fedkovych Chernivtsi National University, Department of Radio \\ Engineering and Information Security, Chernivtsi, Ukraine
}

Abstract. The conditions of ensuring electromagnetic compatibility of radio electronic means of mobile radio service have been analyzed. The stages of such analysis are outlined and a list of measures to be taken at each stage is given. The types of scenarios (paired, group) of interfering radio electronic means of mobile radio service are described. The technical specifications of the radiocommunication service equipment and antennas, which provide a statement of validation of the electromagnetic compatibility of the radiocommunication electronic means radiocommunication, are provided. An algorithm for determining the electromagnetic environment is proposed and recommendations for providing electromagnetic compatibility are offered.

Keywords: electromagnetic compatibility, electromagnetic environment, electronic means, radio communication, mobile service, interference

\section{ŚRODOWISKO KOMPATYBILNOŚCI ELEKTROMAGNETYCZNEJ ŚRODKÓW KOMUNIKACJI RADIOELEKTRONICZNEJ}

\begin{abstract}
Streszczenie. Analizie poddane sq warunki zapewnienia kompatybilności elektromagnetycznej środków radioelektronicznych mobilnych usług radiowych. Przedstawione zostaja etapy takich analiz oraz podana jest lista środków do realizacji na każdym etapie. Opisane sa rodzaje scenariuszy (parami, grupami) interferujących środków radioelektronicznych mobilnych środków radiowych. Podane zostaja techniczne specyfikacje sprzętu ustug radiokomunikacyjnych oraz anten, które przedstawiaja oświadczenie o ważności kompatybilności elektromagnetycznej elektronicznych środków radiokomunikacji. Sugerowany jest algorytm dla określenia środowiska elektromagnetycznego oraz przedstawione zostaja zalecenia dla świadczenia kompatybilności elektromagnetycznej.
\end{abstract}

Słowa kluczowe: kompatybilność elektromagnetyczna, środowisko elektromagnetyczne, środki elektroniczne, komunikacja radiowa, usługi mobilne, interferencja

\section{Introduction}

The analysis of electromagnetic compatibility (EMC) of radioelectronic devices (RED) is currently relevant during the calculation of frequency assignments and is defined by the legislation of the country [7]. The problem of securing EMC RED can be solved in two ways, individually or in combination: technical measures, organizational measures. There are three main stages $[9,10,11]$.

The first stage - the decisions that are made during the design phase of the RED. At this stage, for a given model of electromagnetic environment, the EMC problem can be solved sufficiently accurately and effectively. However, the model cannot really consider all the related factors related to the engineering implementation and production technology (for example, compatibility with adjacent electronic systems, interference from side frequencies and intrinsic heterodyne paths, i.e. intra-system EMC, difficult predictions of related equipment). Therefore, a complete solution to the problem of providing EMC is achieved in the last stages of development and design, manufacture and testing.

The second stage - to perform tests on the EMC criteria and to measure the parameters of the individual RED units and the finished product.

The third stage is the operation, where as a result of various reasons, the REDs operate in conditions different from the calculated ones.

The problem of EMC RED forecasting is traditionally divided into two parts:

1) intra-system EMC, which is characterized by the close location of the RED, accounting for their interaction within a single radio complex and analysis of the characteristics of the antennas in the near and far zones, considering the influence of configuration of the media surface or surrounding devices;

2) intersystem EMC, which is characterized by electrodynamics' interaction of antennas of different radio engineering complexes in the far zone, considering the underlying surface and the conditions of propagation of radio signals through the intermediate medium.

The purpose of the paper is to consider the organizational measures that simplify the analysis of EMC RED mobile service and allow new frequency assignments.

\section{Theory of electromagnetic compatibility}

An increase in the number of radio-electronic devices (REDs), as well as high-frequency generators for industrial, scientific, medical and electro technical devices, which by their functional purpose are not foreseen by sources of radio waves create industrial radio interference. Expanding the scope of REDs led to the gradual saturation of the radio frequency spectrum (RMS) with electromagnetic fields of artificial origin, and together with sources of radio emission (SRE) of natural origin created the problem of electromagnetic compatibility (EMC) of REDs and radio radiation devices (RRD) problems in their design and operation. In general, electromagnetic compatibility is the ability of REDs and RRDs to function simultaneously with conditioned quality in actual operating conditions, taking into account the effects of unintended radio interference on them, without creating unacceptable radio interference with other REDs and RRDs.

The causes and ways of occurrence of electromagnetic interference. The electromagnetic radiation of any RED is concentrated both in the band of its operating frequency (main radiation) and outside of this band (non-basic radiation). Both basic and non-basic radiation when used, for example, directional antennas can propagate both in the direction of the main petal of the radiation pattern and in the lateral and posterior petals. Despite the fact that the gain of directional antennas in the direction of the main petal reaches $50 \mathrm{~dB}$, the gain in the directions of the posterior and lateral petals of the radiation pattern remains quite high (from minus 20 to minus $40 \mathrm{~dB}$ ). As a result, for example, high-power radar stations can emit power outputs of $1 \mathrm{~kW}$ or more along the back and side lobes. And in the direction of the main and side 27 of the antenna petals the electromagnetic waves are emitted with both working polarization and polarization, the parameters of which are different from the working. In this regard, in the receiving antenna and the subsequent paths of the radio receiving device (RRD) for the selection of electromagnetic oscillations of the working radio channel it is necessary to apply the different types of selection - frequency, spatial, polarization, etc. The electromagnetic situation also depends on the radiation that accompanies the main radiation, such as a radio transmitter, and it is manifested by the nonlinear properties of the volt-ampere characteristics of its individual elements. This further complicates the real electromagnetic environment at the receiving point. 
Thus, in order to achieve the EMC when more than one RED is required simultaneously within the same radio frequency space, it is necessary to increase the electromagnetic efficiency of the RED, i.e. to improve certain radiation and / or reception parameters. Ideally, by improving these RED parameters and bringing them to perfection, as well as by optimizing the "placement" of RED frequencies in the RF space, it is possible to obtain its maximum capacity. Under such ideal conditions, the transmitting REDs emit only the necessary signals in the required frequency band and with minimal power only at a given point in space, and the receiving REDs receive signals at the tuning frequency and only from the specified direction.

\section{Methodology for calculation of the EMC RED}

The EMC RED calculation of the mobile radio service is carried out in accordance with a procedure consisting of six consecutive steps, namely $[7,8]$ :

1) preliminary assessment of the electromagnetic environment (EME) in the planning area of the new frequency assignment;

2) preliminary assessment of the proper quality of functioning of individual RESs or the totality of REDs in a given EME;

3) identification of scenarios of interfering RED interaction in the area of planning of new frequency assignment;

4) determination of the characteristics of the RED for the EMC calculations of the RED;

5) calculation of the EMC RED in accordance with the defined interference interaction scenarios;

6) estimation of providing the EMC RED on the results of the performed calculations.

In the first stage, a preliminary evaluation of the EME is carried out within the area of planning of new frequency assignment by territorial and frequency selection of potentially incompatible REDs [1, 3, 4].

In the analysis of EMC RED of duplex radio communications, the EME is evaluated in two steps. In the first stage, the cases of possible interference with existing REDs are evaluated with a new RED. The second stage considers the cases when a new RED may be a source of interfering RED.

In the second stage, the preliminary evaluation of the quality of functioning of individual REDs or their totality is carried out on the basis of basic requirements for the operation of REDs and the quality of communication taking into account the technical characteristics of the REDs and EMEs studied within the area of planning of new frequency assignment [3].

The third stage is the determination of the interaction scenario for the planned REDs and REDs that have fallen into the calculation zone, and is carried out according to the results of a preliminary assessment of the interference situation in the frequency assignment planning area [9]. The scenarios of interfering interaction between the RED of the mobile radio service and the RED of other radio services are divided into pairs and groups. In the paired scenarios, the effect of one unintentional interference (one RED) on one receptor (the other RED) is investigated. In the group scenarios, the effect of a set of interference sources (several REDs) on one receptor is investigated. This must take into account the deployment conditions, antenna directional characteristics, territorial diversity and spatial orientation of the planned and operational RED.

Taking into account that:

1) in the most typical cases, the main factors determining the obstacles in the land mobile service include:

- products in the band of intermodulation frequencies generated by two (or more) powerful interfering signals;

- unwanted radiation that may occur in the transmitter when third-party signals from another transmitter appear in its output RF cascades;

- levels of useful interfering signals are random variables;

2) two (or more) unwanted signals must have such specific frequencies that the products of their intermodulation fall into the frequency band of the receiver;
3) the likelihood of intermodulation interference caused by the interaction of more than two powerful undesired signals is very low;

4) intermodulation interference calculation procedures are a useful tool to ensure more efficient use of spectrum in the land mobile service;

recommended that the intermodulation model of the receiver shown in Fig. 1 to be used in the calculation of intermodulation interference in the land mobile service, and intermodulation interference calculations were performed using intermodulation models in the transmitter and receiver.

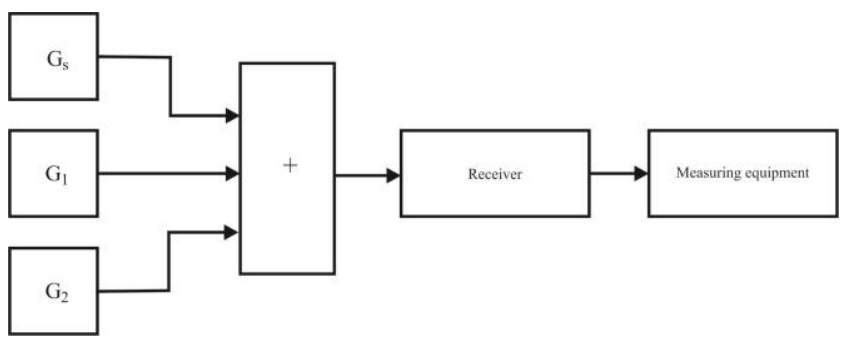

Fig. 1. Block scheme of measurements of intermodulation in the receiver

When measuring the intermodulation characteristics of the receiver, two signals of the same level from the generators $G_{l}$ and $G_{2}$ and a useful signal from the generator $G_{S}$ with the level $P_{c}$ are fed to its input. The frequency disorder of the first generator is selected equal to $\Delta f_{0}$, and the second generator is approximately equal to $2 \Delta f_{0}$. The levels of both generators at the input of the receiver are increased until the level is reached, when the quality of the reception of the useful signal does not start to fall below some set level. The reception quality is clearly related to the protective ratio $A=P_{C}-P_{I}$, where $P_{I}$ is the equivalent interference power listed before the receiver input $(\mathrm{dBm})$.

The general formula for calculating intermodulation interference in a receiver is as follows:

$$
P_{\mathrm{IM}}=2\left(P_{1}-\beta_{1}\right)+\left(P_{2}-\beta_{2}\right)-K_{2,1}
$$

where $P_{1}$ and $P_{2}$ are the interference power of the frequencies $f_{l}$ and $f_{2}$, respectively; $P_{3 i}$ is the power of third-order intermodulation products at frequency $f_{0}\left(f_{0}=2 f_{1}-f_{2}\right) ; K_{2,1}$ is the third order intermodulation coefficient, which can be calculated by means of third order intermodulation measurements, or obtained from the description of equipment characteristics; $\beta_{1}$ and $\beta_{2}$ are radio frequency selectivity parameters at deviations of frequency $\Delta f_{l}$ and $\Delta f_{2}$ from operating frequency $f_{0}$, respectively.

Values $\beta_{1}$ and $\beta_{2}$, for example, can be obtained from the equation to calculate the attenuation of the signal at a non-tuned frequency

$$
\beta(\Delta f)=60 \log \left[1+\left(\frac{2 \Delta f}{B_{\mathrm{RF}}}\right)^{2}\right],
$$

where $B_{R F}$ is the bandwidth of the receiver on the radio frequency.

It should be noted that for a certain set of third-order intermodulation measurements for analogue terrestrial mobile radio receivers operating in the UHF band and the lower frequency of the UHF band, equation (1) can be converted to the form:

$$
P_{\mathrm{IM}}=2 P_{1}+P_{2}+10-60 \log (\sigma f),
$$

where $\sigma f$ is the average frequency deviation (MHz), equal $\left(\Delta f_{1}+\Delta f_{2}\right) / 2$.

The power $P_{i}$ of the products of intermodulation arising in the transmitter and then entering on the receiver input, can be determined by the formula:

$$
P_{i}=P_{2}^{o}-\beta_{12}-\beta_{10}-K_{(2), 1}-L_{10},
$$

where $P_{2}{ }^{o}$ is the power of the interfering transmitter (at frequency $f_{2}$ ) at the output of the faulty transmitter (operating at frequency $f_{l}$ ) in which occur the intermodulation products $(\mathrm{dBW}) ; \beta_{12}, \beta_{10}$ are suppression performed by the output circuits of the faulty transmitter at the frequency $f_{1}$ and feeders of its antenna with respect to the interfering transmitter at the frequency $f_{2}$, and to the products of intermodulation at the frequency $f_{0}$, respectively $(\mathrm{dB})$; $K_{(2), I}$ is the losses of intermodulation transformation in the 
transmitter $(\mathrm{dB})$, which differ from $K_{2,1}$ in formula (1); $L_{10}$ is the attenuation of intermodulation products on-track between transmitter that work on the frequency $f_{l}$ and the receiver $(\mathrm{dB})$.

Interference caused by the transmitter occurs if $P_{S}-P_{i}<A$.

In the fourth stage, the technical characteristics of the RED for which the new frequency assignment is planned and used in the calculations of the EMC RED will be submitted by the applicant together with the application for the issuance of an opinion on the
EMC RED of the mobile radio communication. The application is sent directly to the Radio Frequency Center (RFC). At the same time the following technical characteristics of RED are provided: range of working frequencies of RED, MHz; duplicate radio frequency diversity; frequency grid step or channel formation formula; polarization; radiation bandwidth at $-30 \mathrm{~dB}$; radiation class.

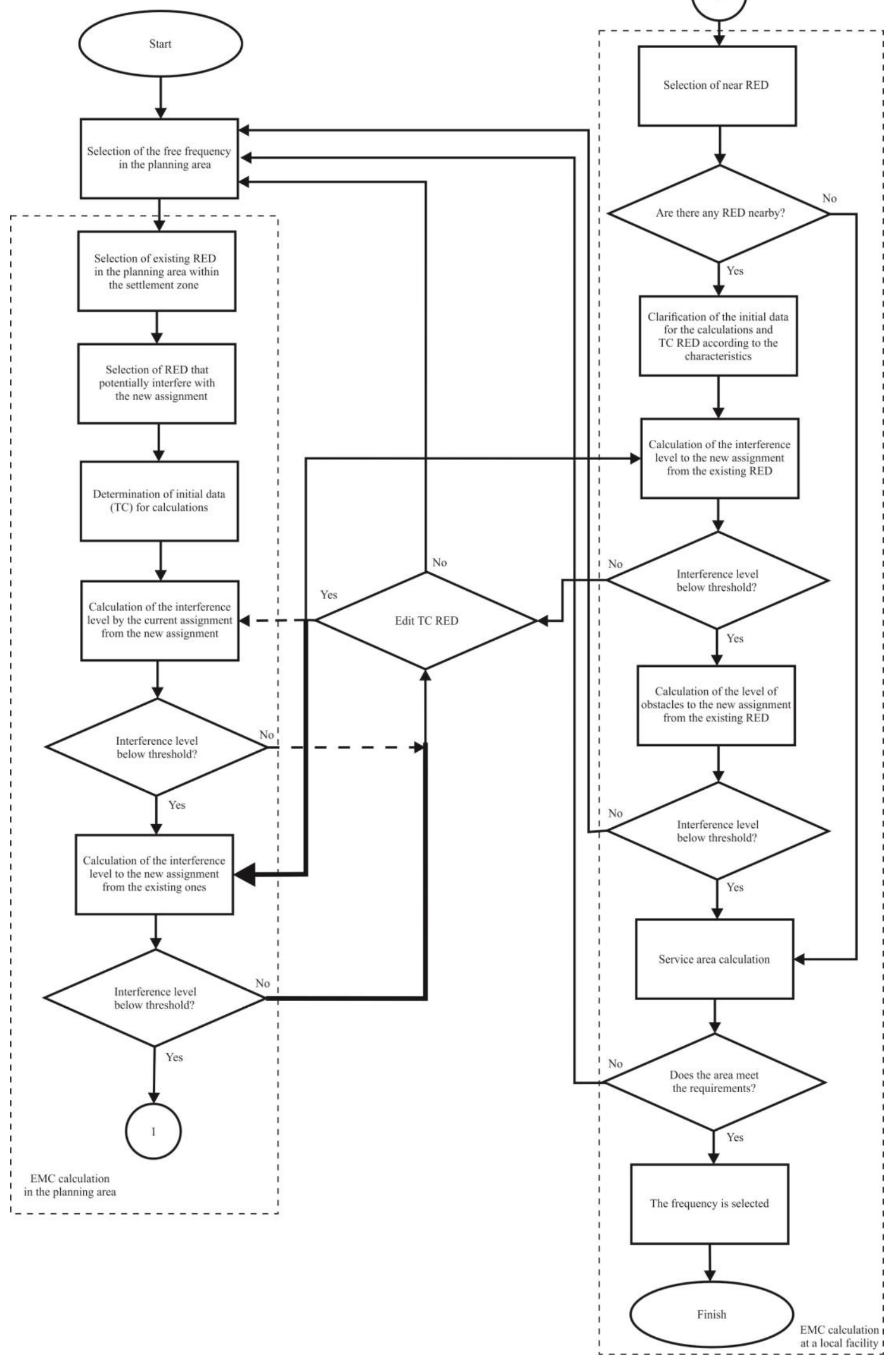


In the fifth stage, the EMC RED of the mobile radio communication is calculated in accordance with the algorithm, the block diagram of which is shown in Fig. 2 [2]. In this paper, this algorithm has been refined and corrected. The EMC calculations of REDs necessarily take into account the type of scenario of interfering RED interaction, which are considered as potential conflicts, types of interferences, channels of possible penetration of interferences (main and non-fundamental) and negative phenomena, which are determined by the frequency selection of conflicting REDs.

In the sixth stage, the provision of the EMC RED is evaluated by checking the fulfillment of the generalized energy criterion of the EMC RED, according to the formula [5, 6]: $P_{S} / P_{i} \geq A(\Delta f)$, where $P_{S}$ is the useful signal power at the receiver input; $P_{i}$ is the power of interference at the input of the receiver (for group scenarios - the total level of interference at the input of the receiver); $A(\Delta f)$ is the protective ratio of the receiver to the interference receptor. The following parameters should be considered when checking the fulfillment of a certain EMC RED criterion: the percentage of time during which communication deterioration is observed due to interference and non-compliance with the EMC RED conditions; the percentage of places that do not meet the conditions of EMC RED; permissible intensity of the interference signal field at the border of the service area; field strength of the payload signal, which guarantees the proper quality of operation of the subscriber terminals in the service area of the base station.

In the international coordination of frequency assignments, the verification of the EMC RED conditions is carried out by the following indicators: the permissible intensity of the interference signal field at a certain point; the maximum range of the interference signal.

\section{Algorithm calculation for the EMC RED}

The EMC RED calculation of the mobile service is performed according to the algorithm (Fig. 2). For the selected radio frequency, consecutive calculations are carried out to evaluate the impact of the new RED on the existing RED and the impact of the existing RED on the new RED depending on the scenario selected [2]. The obtained results of the calculations check the fulfillment of the EMC criterion RED, defined by the formula (the sixth stage).

If the aforementioned EMC RED criterion is not fulfilled, the possibility of changing the technical characteristics of the RED is determined or a decision is made to select another frequency for the new planned RED.

This algorithm can be used in different programming languages, such as Delphi, $\mathrm{C}++$.

\section{Conclusions}

The paper determines the relevance of the analysis of the EMC RED mobile radio service when making frequency assignments. The stages of calculating the EMC RED of the mobile radio service, as well as the list of measures taken at each stage, are outlined. An algorithm for calculating the EMC RED of a mobile radio service is proposed. The suggestions provided make it possible to calculate the EMC RED parameters of the mobile radio service. This analysis should be used when assigning radio frequencies to the mobile radio service RED, as well as during the practical calculations and determining the EMC conditions of the mobile radio service RED.

\section{References}

[1] Burrell J.: Disruptive Effects of Electromagnetic Interference on Communication and Electronic Systems,

http://citeseerx.ist.psu.edu/viewdoc/download?doi=10.1.1.196.1450\&rep=rep1 \&type $=$ pdf

[2] GOST 29037-91. Electromagnetic compatibility of technical means Certification test. General rules. Moscow 2006, http://gostrf.com/normadata/1/4294825/4294825646.pdf

[3] Recommendation P.452: Prediction procedure for the evaluation of interference between stations on the surface of the Earth at frequencies above about $0.1 \mathrm{GHz}$ Managed by R00-SG03, https://www.itu.int/dms_pubrec/itur/rec/p/R-REC-P.452-16-201507-I!!PDF-E.pdf (available 01.12.2017).

[4] Recommendation P.530: Propagation data and prediction methods required for the design of terrestrial line-of-sight systems. Managed by R00-SG03, https://www.itu.int/dms_pubrec/itu-r/rec/p/R-REC-P.530-17-201712-I!!PDFE.pdf (available 01.12.2017).

[5] Recommendation SM.1134: Intermodulation interference calculations in the land-mobile service. Managed by R00-SG01, https://www.itu.int/rec/R-RECSM.1134/en (available 01.02.2007)

[6] Recommendation SM.337-6: Frequency and distance separations. Status: In force (Main), http://www.itu.int/dms_pubrec/itu-r/rec/sm/R-REC-SM.337-6200810-I!!PDF-E.pdf (available 22.10.2008).

[7] Rishennya N2151 (02.12.2008) Pro zatverdzhennya Poryadku rozrobky vysnovkiv shchodo elektromahnitnoyi sumisnosti radioelektronnykh zasobiv movlennya, neobkhidnykh dlya stvorennya ta rozvytku kanaliv movlennya, merezh movlennya ta telemerezh,

https://zakon.rada.gov.ua/rada/show/vr215295-08/ed20160210.

[8] Rozorinov G. M., Lazarenko S. V.: The analysis of electromagnetic compatibility of radio-electronic devices of mobile radio service for frequency assignments Scientific Proceeding of Ukrainian Research Institute of Communication 1(41)/2016, 14-19.

[9] Schneider-Electric: Vol. 32. EMC www.schneider-electric.com.ua (available 10.02.2016)

[10] Sedelnikov Yu.E.: Electromagnetic compatibility of radio electronic means: a training manual. New Knowledge, Kazan 2006 (in Russian).

[11] Suman M., Saini E-M., Sharma A.: Electromagnetic Interference and Compatibility - A Review. International Journal of Advanced Research in Computer Science 8(4)/2017, 355-357.

\begin{abstract}
D.Sc. Heorhii Rozorinov
e-mail: grozoryn@gmail.com

National Technical University of Ukraine "Igor Sikorsky Kyiv Politechnic Institute"

Department of Audiotechnic and Information Registration. D.Sc. (Engineering Sciences) Professor of Department of Audiotechnic and Information Registration. Research interests: pseudorandom sequence generators; encryption information, acoustics.

Author of nearly 120 publications.
\end{abstract}

http://orcid.org/0000-0002-6095-7539

\section{M.Sc. Oleksandr Hres}

e-mail: o.hres@chnu.edu.ua

Yuriy Fedkovych, Chernivtsi National University Department of Radio Engineering and Information Security. Assistant Professor of Department of Radio Engineering and Information Security.

Research interests: pseudorandom sequence generators; encryption information. Author of nearly 35 publications.

http://orcid.org/0000-0002-8465-193X

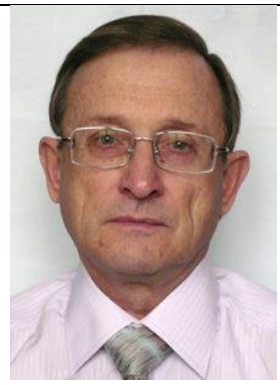

Ph.D. Volodymyr Rusyn

e-mail: rusyn_v@ukr.net

Yuriy Fedkovych Chernivtsi National University Department of Radio Engineering and Information Security. Ph.D. (Engineering Sciences) Assistant Professor of Department of Radio Engineering and Information Security. Research interests: modeling of nonlinear equations and chaotic generators; control of chaotic oscillations. Author of nearly 60 publications.

http://orcid.org/0000-0001-6219-1031

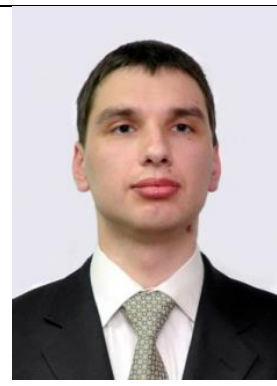

Ph.D. Petro Shpata

e-mail: p.shpatar@chnu.edu.ua

Yuriy Fedkovych Chernivtsi National University Department of Radio Engineering and Information Security. Ph.D. (Engineering Sciences) Associate Professor of Department of Radio Engineering and Information Security. Research interests: pseudorandom sequence generators; encryption information. Author of nearly 60 publications.

http://orcid.org/0000-0003-4088-1458
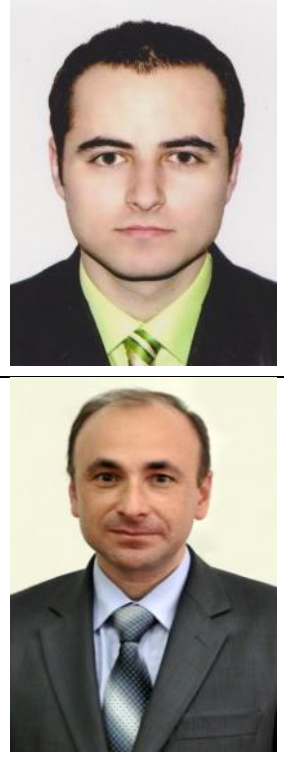

otrzymano/received: 15.11.2019

przyjęto do druku/accepted: 15.02 .2020 